\title{
INTRO EINLEITUNG
}

Amongst the achievements developed in carpentry and wood construction within various cultures, climatic conditions and geographies, the refined principle of plug-in connections is a powerful manifestation. The use of solid wood for construction offers the potential to shape the structural members in a way that they can be directly connected, without the need for additional fasteners. This results in a low-tech form of assembly of interlocking members that can be used to compose flexible, temporary structures. This practice especially originates from Europe and Asia. $\nearrow^{02}$ Today, it could be considered as an axiom for a future-oriented technique for building constructions out of parts that can be disand reassembled. $\nearrow^{03}$

Enabled by digital tools and CNC manufacturing, Interlocking Spaces $(I S)$ investigated the design and fabrication of complex structures from standard timber elements that employ the concept of interlocking on both a detail and a global level, mediating between modularity and irregularity, systematics and intuition, and digital and analog practices. Traditional joinery techniques have inspired a design methodology that combines a material-oriented approach, technology and intuition in order to test a possible model for a contemporary practice of design and crafting. $\nearrow^{04}$

Excursions to important carpentry-related environments, such as traditional and state-of-the-art woodworking companies and research institutions in the European Alpine region and Japan, inspired preliminary concepts for this project. Japanese culture in particular had a critical influence on further developments. An exchange of thoughts and discussions with Jun Sato in Tokyo led to holding a joint workshop with students at the Angewandte in Vienna, which initiated a process of investigations on various scales that primarily resulted in two large-scale installations ( $I S-1$ and $I S-2)$ and a series of prototypical tables $(T-1, T-2 a, T-2 b$ and $T-3 a)$.
Unter den Errungenschaften, die im Zimmerei- und Holzbau innerhalb verschiedener Kulturen, Klimazonen und Geografien entwickelt wurden, ist das raffinierte Prinzip der Steckverbindungen eine kraftvolle Manifestation. Die Verwendung von Massivholz für Konstruktionen hat das Potenzial, die Bauelemente so zu formen, dass sie direkt miteinander verbunden werden können, ohne dass zusätzliche Verbindungselemente erforderlich sind. Daraus ergibt sich eine Low-Tech-Fügetechnik von miteinander verschränkten Bauteilen, mit der sich flexible, temporäre Strukturen bilden lassen. Diese Praxis stammt vor allem aus Europa und Asien. $\nearrow^{02}$ Heute könnte sie als Axiom für eine zukunftsweisende Technik gelten, Konstruktionen aus zerlegbaren und wieder zusammensetzbaren Teilen zu bauen. $\nearrow^{03}$

Mithilfe digitaler Werkzeuge und CNC-Fertigung untersuchte Interlocking Spaces (IS) Entwurf und Herstellung komplexer Strukturen aus Standard-Holzelementen, die das Konzept der Verschränkung sowohl auf einer Detail- als auch auf einer globalen Ebene anwenden und zwischen Modularität und Unregelmäßigkeit, Systematik und Intuition sowie digitalen und analogen Praktiken vermitteln. Traditionelle Holzverbindungen haben eine Entwurfsmethodik inspiriert, die eine materialorientierte Herangehensweise, Technologie und Intuition kombiniert, um ein mögliches Modell für eine zeitgemäße Praxis von Design und Handwerk zu testen. $\nearrow^{04}$

Erfahrungen aus Exkursionen zu wichtigen Umfeldern des Holzbaus, zum Beispiel traditionelle und moderne holzverarbeitende Betriebe und Forschungseinrichtungen im europäischen Alpenraum und in Japan, inspirierten erste Konzepte für dieses Projekt. Insbesondere die japanische Kultur hatte einen entscheidenden Einfluss auf die weiteren Entwicklungen. Ein Gedankenaustausch und Diskussionen mit Jun Sato in Tokio führten zu einem gemeinsamen Workshop mit Studierenden der Angewandten in Wien, der einen Prozess von Untersuchungen in verschiedenen Maßstäben einleitete. Als Ergebnis entstanden unter anderem zwei großflächige Installationen ( $I S-1$ und $I S-2)$ und eine Reihe von prototypischen Tischen (T-1, T-2a, T-2b und T-3a). 
